Section Editor

Mitchell S.V. Elkind, MD, MS

\title{
Teaching NeuroImages: \\ MRI of brain findings of Wolfram (DIDMOAD) syndrome
}

Rahsan Gocmen, MD

Ezgi Guler, MD

Correspondence to

Dr. Guler:

gulerezgi@yahoo.com

Figure $1 \quad$ Brain MRI findings of a 31-year-old woman with Wolfram syndrome

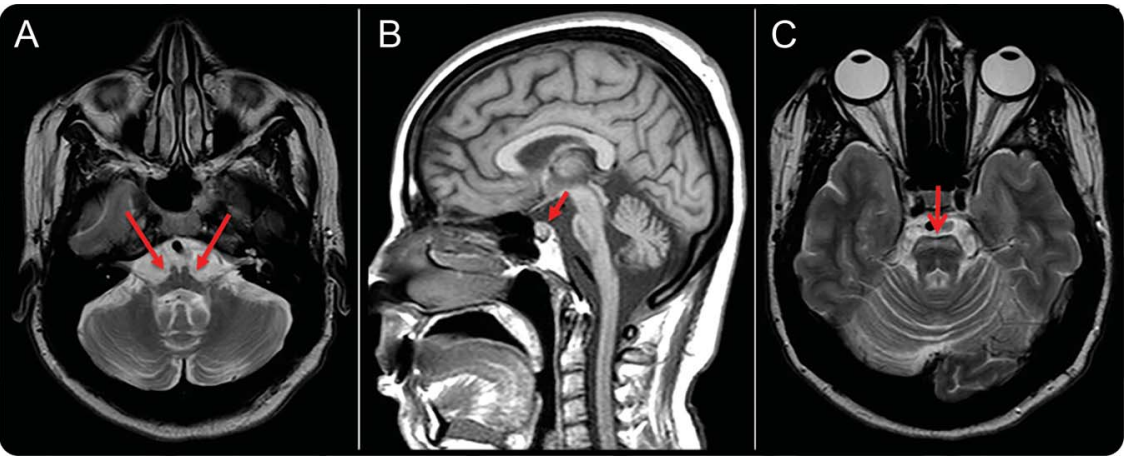

Axial T2-weighted image (A) and sagittal T1-weighted image $(B)$ demonstrate atrophy of brainstem. Note absence of neurohypophyseal "bright signal" on sagittal T1 image (B). T2-weighted image (C) shows atrophy of cerebellum and hyperintense signal at ventral part of the pons.

A 31-year-old woman was diagnosed with type 1 diabetes mellitus (DM) at age 5 years and subsequently with hypothyroidism at age 16 years. She developed progressive visual loss at age 19 years and progressive hearing loss at age 28 years. She was clinically and radiologically diagnosed with Wolfram syndrome (figures 1 and 2). Wolfram syndrome, first described in 1938 , is a rare autosomal recessive disorder. ${ }^{1}$ It features diabetes insipidus (DI), DM, optic atrophy $(\mathrm{OA})$, and deafness (D) (DIDMOAD)., ${ }^{1,2}$ It is caused by a mutation in the WFS1 gene that encodes wolframin, a transmembrane protein of pancreatic $\beta$ cells. $^{1}$

Figure 2 Optic nerve and optic tract findings

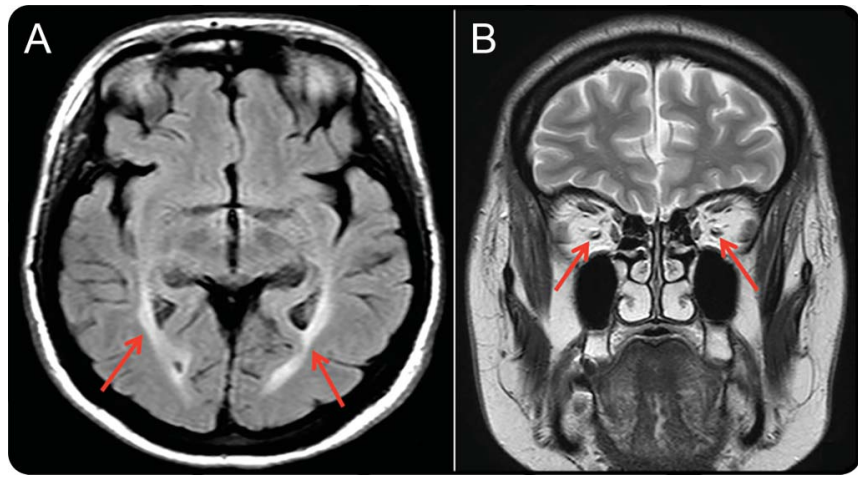

Axial fluid-attenuated inversion recovery image (A) demonstrates increased signal intensity in the bilateral peritrigonal areas/optic tracts. Coronal T2-weighted image (B) shows thinning/atrophy of bilateral optic nerves (arrows).

Download teaching slides: Neurology.org

From the Department of Radiology (R.G.), Faculty of Medicine, Hacettepe University, Ankara; and the Department of Radiology (E.G.), Rize State Hospital, Turkey.

Go to Neurology.org for full disclosures. Funding information and disclosures deemed relevant by the authors, if any, are provided at the end of the article. 
The life expectancy of patients diagnosed with this syndrome is about 30 years.

\section{AUTHOR CONTRIBUTIONS}

Rahsan Gocmen interpreted neuroradiologic aspects of this article including formatting of the figure and other professional comments, assisted in drafting, and revised the manuscript for intellectual content. Ezgi Guler wrote the draft, collected the information, compiled the manuscript, and assisted in drafting and preparing the manuscript for publication.

\section{STUDY FUNDING}

No targeted funding reported.

\section{DISCLOSURE}

The authors report no disclosures relevant to the manuscript. Go to Neurology.org for full disclosures.

\section{REFERENCES}

1. Scolding NJ, Kellar-Wood HF, Shaw C, Shneerson JM, Antoun N. Wolfram syndrome: hereditary diabetes mellitus with brainstem and optic atrophy. Ann Neurol 1996;39: 352-360.

2. Ito S, Sakakibara R, Hattori T. Wolfram syndrome presenting marked brain MR imaging abnormalities with few neurologic abnormalities. AJNR Am J Neuroradiol 2007;28: 305-306. 


\section{Neurology}

\section{Teaching NeuroImages: MRI of brain findings of Wolfram (DIDMOAD) syndrome Rahsan Gocmen and Ezgi Guler \\ Neurology 2014;83;e213-e214 \\ DOI 10.1212/WNL.0000000000001082}

\section{This information is current as of December 8, 2014}

\section{Updated Information \& Services}

Supplementary Material

References

Citations

Subspecialty Collections

Permissions \& Licensing

Reprints including high resolution figures, can be found at: http://n.neurology.org/content/83/24/e213.full

Supplementary material can be found at: http://n.neurology.org/content/suppl/2014/12/07/WNL.0000000000001 082.DC1

This article cites 2 articles, 0 of which you can access for free at: http://n.neurology.org/content/83/24/e213.full\#ref-list-1

This article has been cited by 1 HighWire-hosted articles: http://n.neurology.org/content/83/24/e213.full\#\#otherarticles

This article, along with others on similar topics, appears in the following collection(s):

Genetic linkage

http://n.neurology.org/cgi/collection/genetic_linkage

MRI

http://n.neurology.org/cgi/collection/mri

Information about reproducing this article in parts (figures,tables) or in its entirety can be found online at:

http://www.neurology.org/about/about_the_journal\#permissions

Information about ordering reprints can be found online: http://n.neurology.org/subscribers/advertise

Neurology ${ }^{\circledR}$ is the official journal of the American Academy of Neurology. Published continuously since 1951, it is now a weekly with 48 issues per year. Copyright @ 2014 American Academy of Neurology. All rights reserved. Print ISSN: 0028-3878. Online ISSN: 1526-632X.

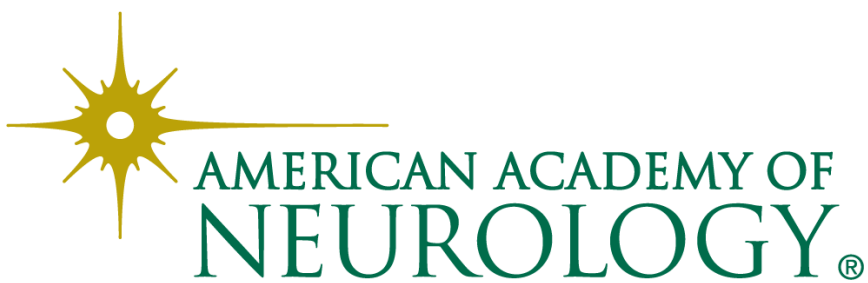

